\title{
Analisis Kekritisan Sodium-Cooled Fast Reactor (SFR) Berdasarkan Variasi Bahan Bakar
}

\author{
Revina Septi $^{* 1}$, M. Ali Shafiii', Feriska Handayani Irka ${ }^{1}$, Zaki Su’ud ${ }^{2}$ \\ ${ }^{1}$ Jurusan Fisika FMIPA Universitas Andalas \\ ${ }^{2}$ Laboratorium Nuklir dan Biofisika Institut Teknologi Bandung \\ *septirevina0309@gmail.com
}

\begin{abstract}
ABSTRAK
Analisis kekritisan Sodium-Cooled Fast Reactor (SFR) berdasarkan variasi bahan bakar telah dilakukan. Variasi bahan bakar yang digunakan adalah MOX, UN-PuN, dan U-Zr. Reaktor ini menggunakan natrium sebagai pendingin dan parameter yang diamati adalah faktor multiplikasi $\left(k_{e f f}\right)$ pada teras reaktor. Penelitian ini dilakukan secara simulasi komputasi meggunakan kode SRAC (Standard Thermal Reactor Analysis Code System) dengan JENDL-32 sebagai library. Teras reaktor dibagi menjadi 10 region arah radial. Pada awal operasi reaktor, masing-masing region diisi dengan bahan bakar uranium alam. Setelah 10 tahun pembakaran, hasil burn up pada region 1 di shuffling ke region 2, hasil region 2 di shuffling ke region 3 dan seterusnya sampai hasil burn up di region 9 di shuffling ke region 10, hasil burn up region 10 dikeluarkan dari teras reaktor dan pada region 1 akan diisi dengan bahan bakar yang baru. Hasil penelitian menunjukkan bahwa bahan bakar MOX dan $\mathrm{U}-\mathrm{Zr}$ memilki nilai $k_{\text {eff }}$ yang paling optimal digunakan pada reaktor SFR.

Kata kunci: faktor multiplikasi $k_{\text {eff }}$, periode burn up, program SRAC, strategi shuffling
\end{abstract}

\section{ABSTRACT}

The analysis of the criticality of the SFR based on the variations of fuel has been done. The fuel variations used are MOX, UN-PuN, and U-Zr. This reactor uses sodium as a coolant and parameters that observed is the multiplication factor $\left(k_{\text {eff }}\right)$ on the reactor core. This research is a simulated computing using the SRAC (Standard Thermal Reactor Analysis Code System) code with JENDL-32 as a library. The reactor core was divided into 10 regions of radial direction. At the beginning of the reactor operation, each region is filled with fuel. After 10 years of burning, the result of burn up in region 1 shuffled to region 2, the result of region 2 shuffled to region 3 and so on until the result of burn up region 9 shuffled to region 10. The result of burn up the region 10 removed from reactor core and at region 1 will be filled with new fuel. The results showed that the MOX and U-Zr fuels have a value multiplication factor is the most optimal used in SFR reactor.

Keywords: burn up period, multiplication factor $\left(k_{\text {eff }}\right)$ shuffling strategi, SRAC program

\section{PENDAHULUAN}

Sodium Cooled Fast Reactor (SFR) termasuk jenis reaktor generasi ke-IV dengan Natrium sebagai pendinginnya (Suwoto dan Zuhair, 2012). SFR memiliki siklus bahan bakar tertutup yang mempunyai temperatur keluaran sekitar $510^{\circ} \mathrm{C}-550^{\circ} \mathrm{C}$ dengan rentang daya 1500 $1700 \mathrm{MWe}$, selain itu sodium atau natrium berbentuk padat pada temperatur kamar dan mencair pada temperatur $98,1^{\circ} \mathrm{C}$ dan mulai menguap pada suhu $892^{\circ} \mathrm{C}$. Sodium memiliki temperatur operasi yang lebar dibanding air biasa $\left(\mathrm{H}_{2} \mathrm{O}\right)$ dan mempunyai panas spesifik yang besar, maka sangat bagus digunakan sebagai media perpindahan panas (Suwoto dan Zuhair, 2009).

Perancangan reaktor memerlukan analisis yang komprehensif, yaitu meliputi analisis neutronik, analisis termal hidrolik dan analisis keamanan. Analisis neutronik adalah tahap analisis yang berhubungan dengan perilaku neutron di dalam teras reaktor. Secara umum analisis ini membahas mengenai populasi neutron, fluks neutron, faktor multiplikasi, distribusi sumber neutron, dan distribusi daya.

Faktor multiplikasi menyatakan nilai perbandingan jumlah populasi neutron dalam satu generasi dengan generasi sebelumnya. Harga faktor multiplikasi ini bergantung pada geometri reaktor dan komposisi teras reaktor. Apabila ukuran teras reaktor semakin besar maka akan memberikan peluang lebih besar untuk neutron bertumbukkan sehingga menghasilkan jumlah neutron yang lebih banyak. Hal ini menyebabkan harga faktor multiplikasi neutron semakin besar (Waltar dan Reynolds, 1981).

Penelitian ini menjelaskan tentang analisis kekritisan SFR berdasarkan variasi bahan bakar yaitu U-Zr, UN-PuN, dan MOX. U-Zr merupakan campuran Uranium dengan Zirkonium. 
Zirkonium merupakan material yang tahan terhadap korosi dan memiliki daya serap neutron yang rendah. Bahan bakar UN-PuN adalah bahan bakar campuran yang memiliki titik leleh $\sim 2500{ }^{\circ} \mathrm{C}$ dan konduktivitas termal yang tinggi, sedangkan MOX biasa disebut dengan mixed oxide memiliki temperatur leleh $\sim 2750^{\circ} \mathrm{C}$. Penelitian ini menggunakan strategi shuffling sebagai periode refueling-nya (pengisian bahan bakarnya). Strategi shuffling merupakan strategi yang digunakan agar reaktor dapat beroperasi tanpa dilakukan pengkayaan dan menggunakan uranium alam sebagai bahan bakarnya. Penelitian ini dilakukan untuk mengetahui jenis bahan bakar dengan kinerja neutronik yang optimal digunakan pada reaktor SFR.

\section{METODE}

Desain reaktor nuklir yang digunakan adalah salah satu reaktor generasi IV yaitu reaktor cepat berpendingin sodium (SFR) dengan spektrum neutron cepat menggunakan strategi shuffling arah radial. Desain teras yang digunakan dalam penelitian ini bertipe silinder 2-D, karena ditinjau dari faktor kebocoran neutron (neutron leakage) dan aliran coolant, maka geometri silinder adalah geometri yang memberikan kinerja yang optimal (Guskha, 2016). Secara umum teras dibagi menjadi 11 region arah radial dan 2 region arah axial. Sepuluh region pertama merupakan region untuk menempatkan bahan bakar sedangkan region ke sebelas adalah reflektor.

Diagram alir prosedur perhitungan parameter neutronik menggunakan SRAC dapat dilihat pada Gambar 1 .
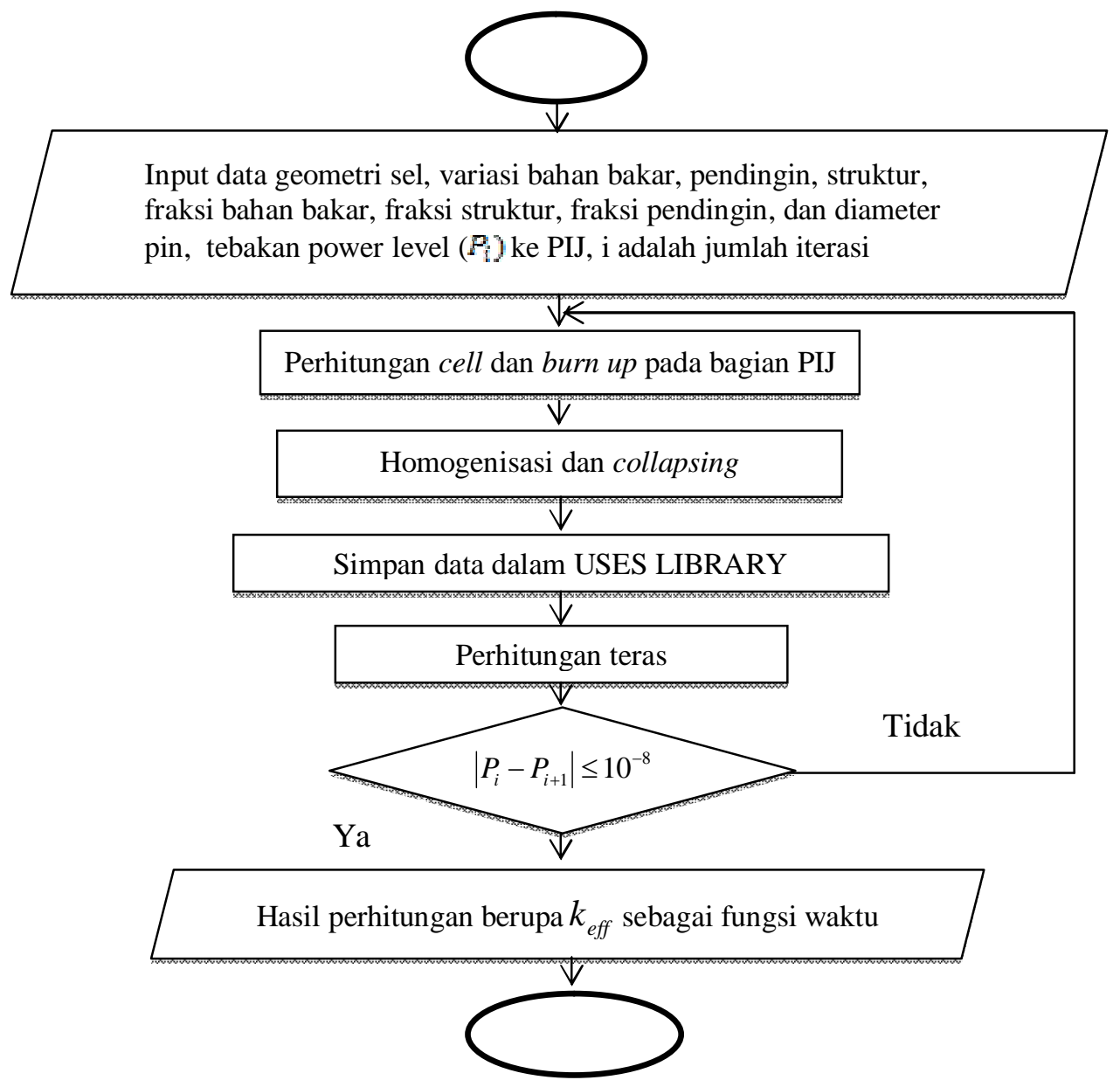

Gambar 1 Diagram alir perhitungan neutronik menggunakan SRAC 

berikut :

Spesifikasi umum desain reaktor yang digunakan dalam penelitian ini adalah sebagai

Tabel 1 Spesifikasi umum desain reaktor

\begin{tabular}{cc}
\hline Parameter & Deskripsi \\
\hline Geometri cell & Cylinder \\
Geometri teras & 2-D Cylinder \\
Jumlah region bervolume sama & \\
dalam arah radial & 10 Region \\
Periode refuelling & 10 Tahun \\
Waktu operasi & 100 Tahun \\
Daya keluaran & 550 MWth \\
Struktur (cladding) & SS316 \\
Bahan bakar & MOX, U-Zr, dan UN-PuN \\
Pendingin (coolant) & Na \\
Fraksi bahan bakar & $51 \%$ \\
Fraksi struktur & $35 \%$ \\
Fraksi pendingin & $14 \%$ \\
Diameter Pin / pitch & $1,4 \mathrm{~cm}$ \\
Tinggi teras aktif & $350 \mathrm{~cm}$ \\
Diameter teras aktif & $240 \mathrm{~cm}$ \\
Lebar reflector & $50 \mathrm{~cm}$ \\
\hline
\end{tabular}

\section{HASIL DAN DISKUSI}

Nilai $k_{\text {eff }}$ merupakan nilai perbandingan jumlah populasi neutron dalam teras reaktor pada satu generasi dengan generasi sebelumnya. $k_{\text {eff }}$ menunjukkan kondisi kekritisan yang memperlihatkan reaktor berada dalam keadaan baik atau tidak. Hubungan $k_{\text {eff }}$ terhadap waktu operasi (periode burn up) untuk berbagai variasi bahan bakar dapat dilihat pada Gambar 2.

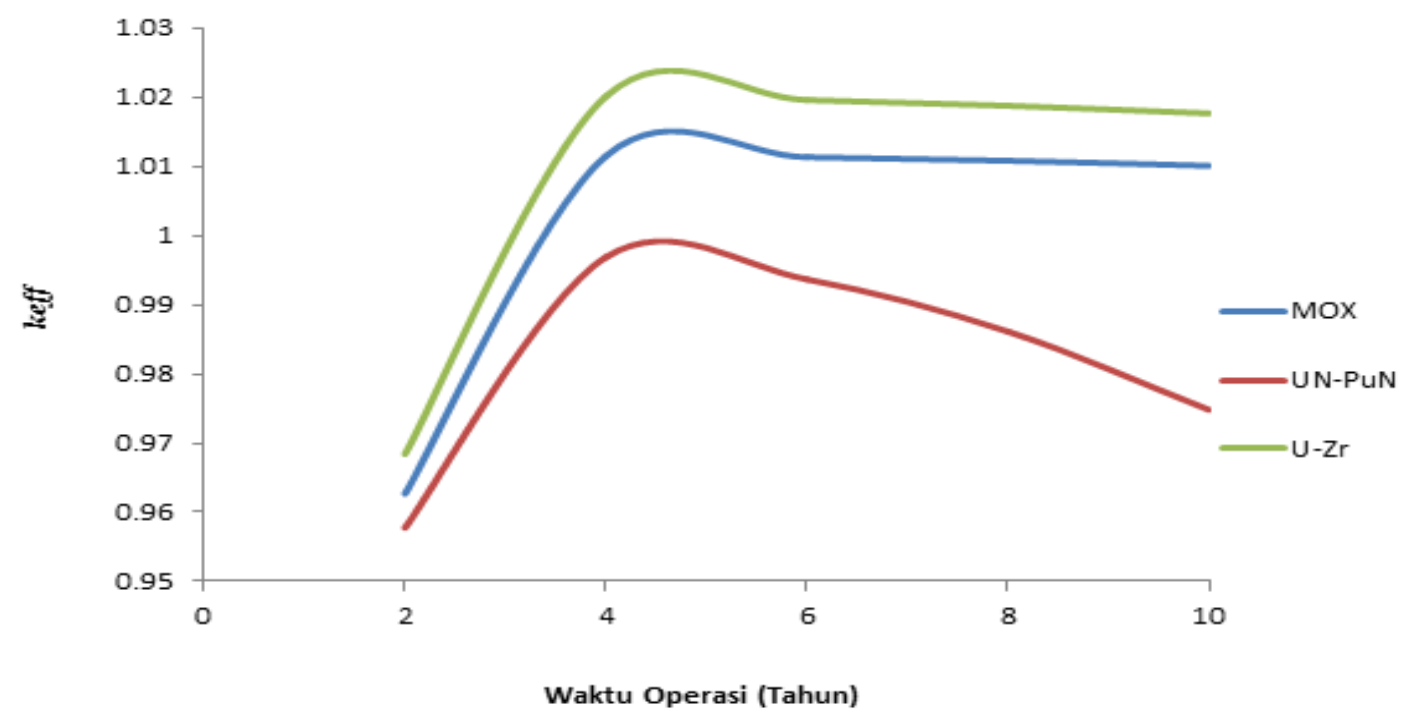

Gambar 2 Hubungan $k_{\text {eff }}$ terhadap periode burn up untuk variasi bahan bakar

Gambar 2 memperlihatkan bahwa reaktor berada pada keadaan kritis. Keadaan kritis adalah nilai $k_{\text {eff }} \approx 1$ dengan reactivity swing (nilai batas toleransi reaktivitas) $\pm 0,05$. Nilai faktor $k_{\text {eff }}$ ditinjau setiap dua tahun sekali dalam rentang 10 tahun periode burn up. Data Gambar 3 merupakan periode awal pembakaran bahan bakar reaktor. Pada awal periode burn up nilai $k_{e f f}$ masing- masing bahan bakar masih kecil, dan pada periode burn up yang kedua nilai $k_{\text {eff }}$ semakin naik hingga mencapai titik kestabilannya. Hal ini dipengaruhi oleh reaksi fisi yang terjadi pada teras reaktor, dimana perubahan bahan fertil menjadi bahan fisil semakin meningkat sehingga mencapai kestabilan ketika jumlah populasi neutronnya terpenuhi. Bahan bakar MOX 
memiliki rentang $k_{\text {eff }} 0,96267-1,01007$, bahan bakar UN-PuN memiliki rentang $k_{\text {eff }} 0,9577568$ 0,974796 dan U-Zr memiliki rentang $k_{\text {eff }}$ 0,96842-1,01766.

Ketiga jenis bahan bakar yang digunakan dapat dihasilkan jenis bahan bakar yang memiliki $k_{\text {eff }}$ yang paling mendekati reaktivity swing yaitu bahan bakar MOX dan U-Zr. Hal ini dipengaruhi oleh densitas dan massa jenis dari bahan bakar tersebut. Semakin besar besar densitas dan massa jenis bahan bakar yang digunakan semakin banyak jumlah neutron yang dihasilkan dari reaksi fisi, sehingga tingkat kekritisan suatu reaktor akan semakin baik. Keberlangsungan reaksi fisi di teras reaktor memerlukan fraksi bahan bakar yang memiliki bahan fisil yang lebih besar.

\section{KESIMPULAN}

Setelah dilakukan perhitungan dan analis neutronik didapatkan kesimpulan bahwa dari ketiga jenis bahan bakar yang digunakan menunjukkan reaktor berada dalam keadaan kritis. Namun dari ketiga jenis bahan bakar yang digunakan, bahan bakar MOX dan U-Zr memiliki nilai $k_{\text {eff }}$ yang paling optimal digunakan pada SFR.

\section{DAFTAR PUSTAKA}

Guskha, C.R., Analisis Densitas Nuklida Lead-Bismuth Cooled Fast Reactor (LFR) Berdasarkan Variasi Daya Keluaran, Jurnal Fisika Unand. 5, 7-13 (2016).

Suwoto dan Zuhair, "Analisis Tampang Lintang Data Nuklir Sodium-23 untuk Pendingin Reaktor Generasi IV-SFR", Buku I Prosiding PPI-PDIPTN-2009, Pusat Teknologi Akselerator dan Proses Bahan, (BATAN, Yogyakarta, 2009), hal. 91-98.

Suwoto dan Zuhair, Studi dan Opservasi Awal Kebutuhan Data Nuklir untuk Reaktor Generasi IV (Gen-IV), Jurnal Ilmu Fisika Indonesia. 1, 18-25 (2012).

Waltar, A.E. dan Reynolds, A.B., Fast Breeder Reactor, (Pergamon Press, U.S.A., 1981), hal. 5-7. 